\section{Lo Contador: casa, barrio, ciudad ${ }^{1}$}

Fernando Pérez Oyarzun Profesor, Facultad de Arquitectura, Diseño y Estudios Urbanos, Pontificia Universidad Católica de Chile

La relevancia de una obra en la construcción, evolución y destino del territorio inmediato donde se inserta, se devela aquí a partir de la lectura de los acontecimientos de una casa patronal a lo largo de los siglos. La reconstrucción del proceso de la obra se establece a partir de diferentes escalas de aproximación: la casa, el barrio y la ciudad.

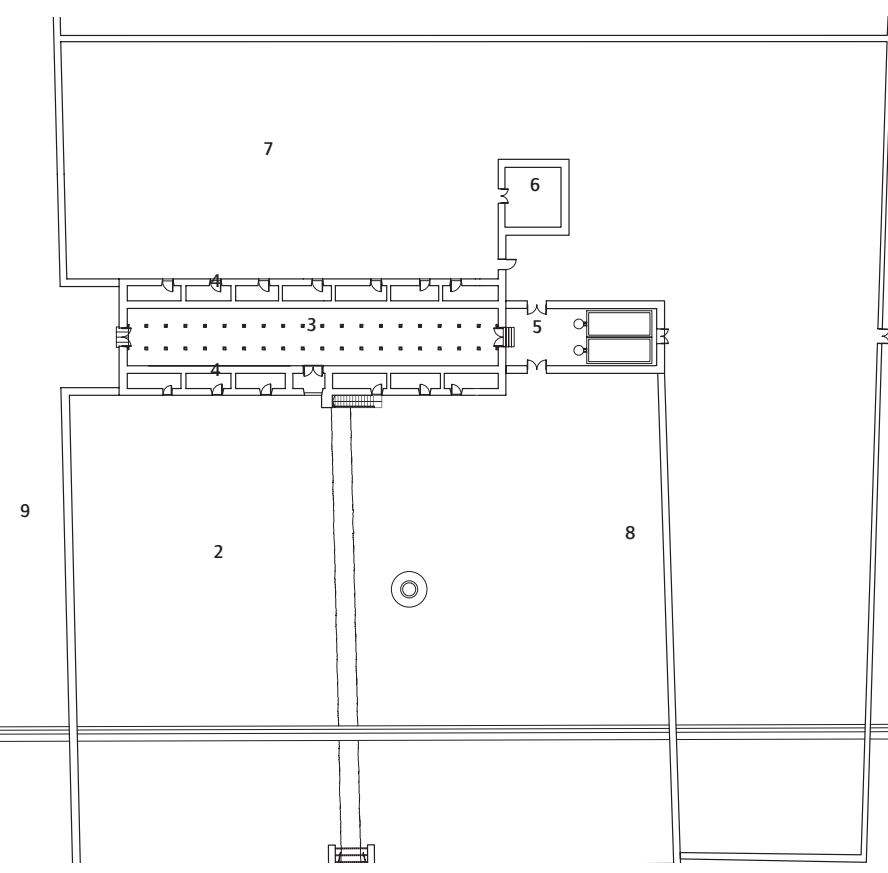

PLANTA 1799 E 1:1000

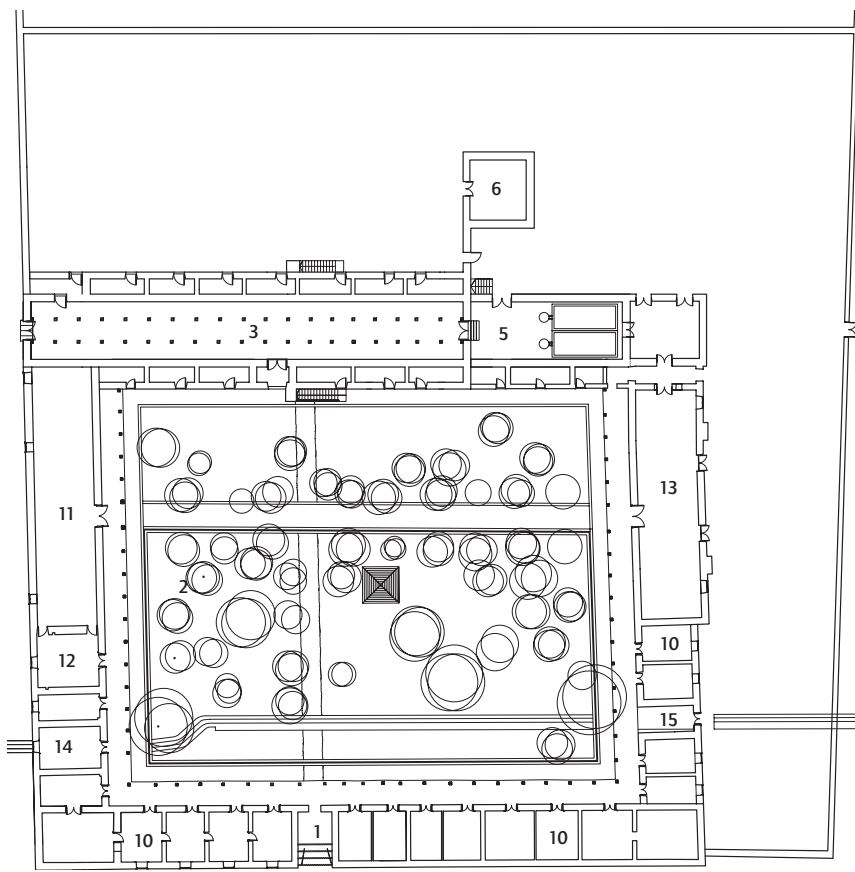

PLANTA 1866

\section{Lo Contador: house, borough, city ${ }^{1}$}

Fernando Pérez Oyarzun Professor, School of Architecture, Design and Urban Studies. Pontificia Universidad Católica de Chile

The relevance of a work in the construction, evolution and use of an immediate territory of which it forms a part are unveiled here in the record of the occurrences in a grange over the centuries. The work process is reconstructed on the basis of different scales of focus: the house, the neighborhood and the city.

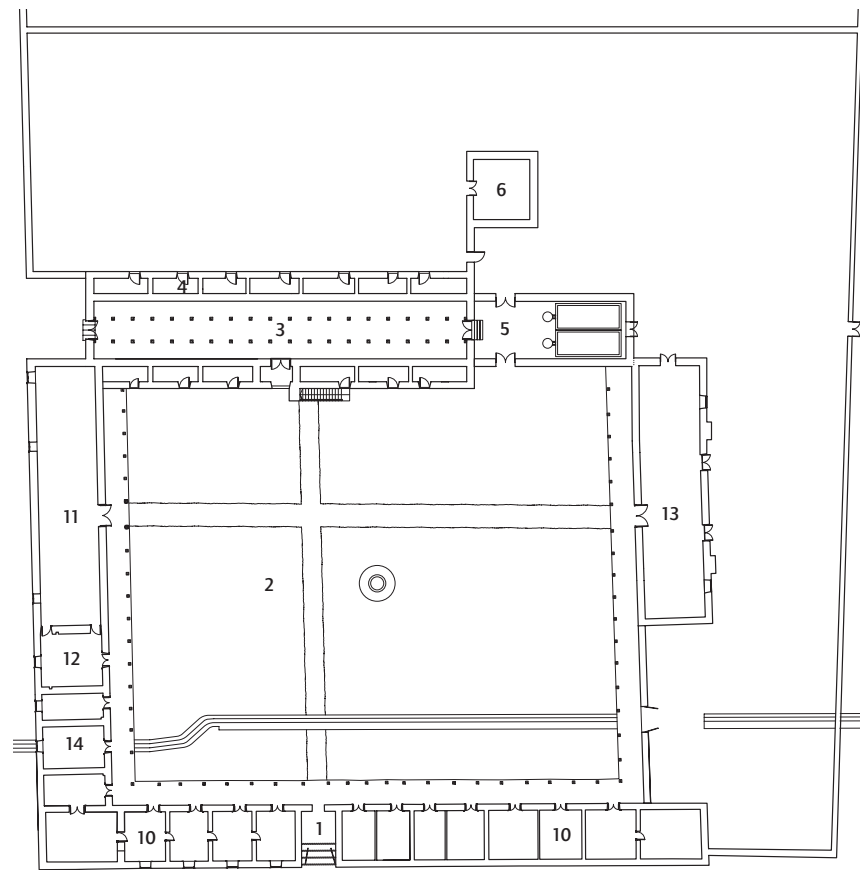

PLANTA 1840

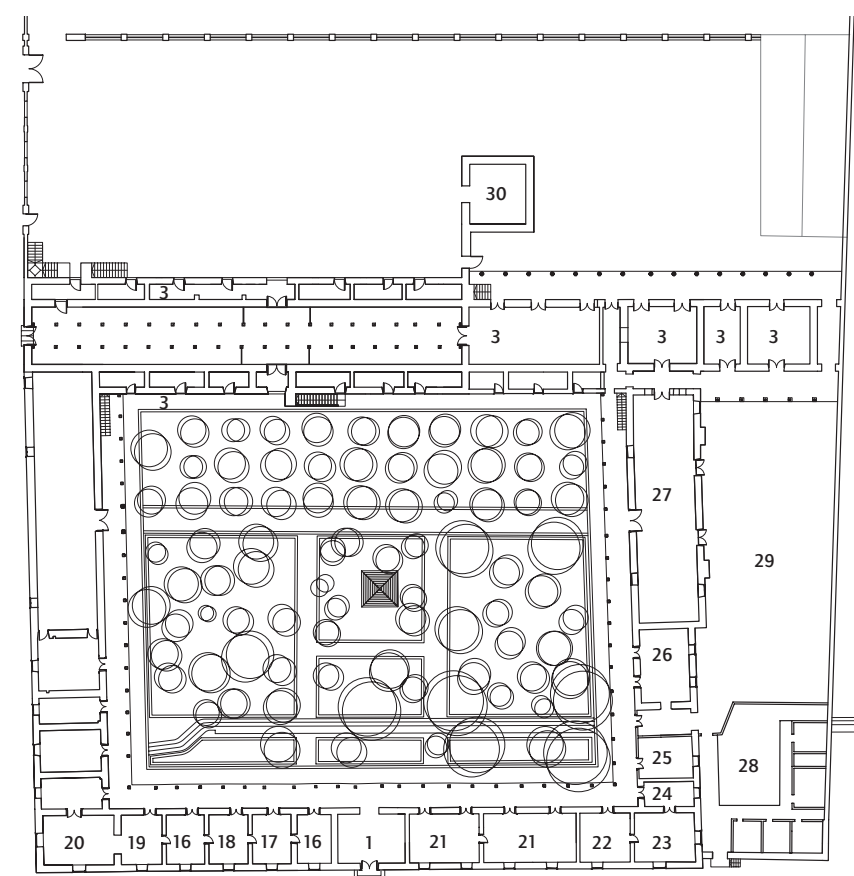

PLANTA 1920

$\begin{array}{lll}1 \text { Zaguán de acceso } & 6 \text { Cocina } & 11 \text { Capilla } \\ 2 \text { Patio principal } & 7 \text { Jardín } & 12 \text { Sacristía } \\ 3 \text { Bodegas } & 8 \text { Patio de los Fondos } & 13 \text { Refectorio } \\ 4 \text { Cuarto de criados } & 9 \text { Callejón } & 14 \text { Baños } \\ 5 \text { Lagares } & 10 \text { Aposentos de ejercitantes } & 15 \text { Foso }\end{array}$

3 Bodegas

5 Lagares
7 Jardin

10 Aposentos de ejercitantes
15 Foso
16 Dormitorio

17 Teléfono

18 Escritorio

19 Sala de música

20 Billar

21 Dormitorio mujeres
22 Comedor niños
23 Comedor
24 Despensa

25 Repostero
26 Cocina

27 Bodegas de herramientas, frutos y pasto 28 Piezas de servicio

29 Gallinero 


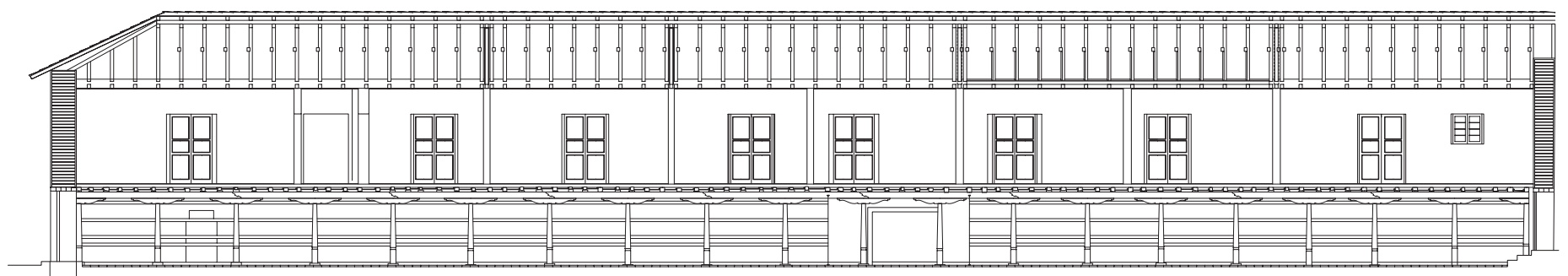

CORTE LONGITUDINAL ALQUERÍA E 1:250

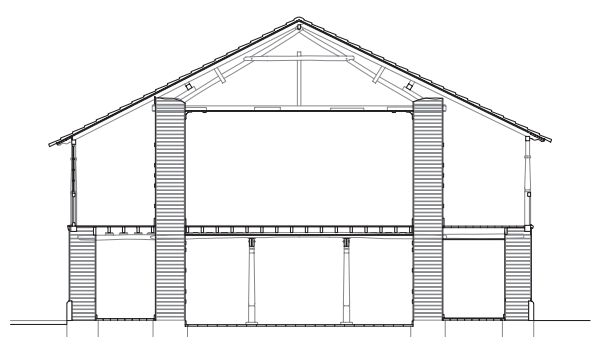

CORTE TRANSVERSAL ALQUERÍA

LO GRANDE Y LO PEQUEÑo / Robin Evans abre su clásico texto Doors Figures and Passages (Evans, 1997) señalando que las cosas ordinarias esconden los misterios más profundos. En un hecho urbano tan acotado como una casa pueden percibirse las huellas de las formas y el sentido del crecimiento de una ciudad ${ }^{2}$. Tales formas de interacción escalar que permite reconocer las huellas de lo mayor en lo menor y viceversa, constituyen una parte muy medular de los fenómenos con que la arquitectura ha debido tratar a lo largo de la historia.

La casa de Lo Contador sita en el que hoy es el barrio de Pedro de Valdivia Norte, en Santiago, ha resistido casi milagrosamente al paso del tiempo y al crecimiento de la ciudad. Hoy, literalmente sumergida en el tejido urbano del barrio, tal vez no sea tan aparente la relación que existe entre ella y el área urbana que la rodea.

Como tantas casas rurales chilenas, Lo Contador es el resultado de un largo proceso de evolución. Este ha dependido de múltiples factores históricos. En primer lugar los propietarios y las formas de explotación productiva. Sin embargo ella no es ajena a los procesos de desarrollo de la ciudad de Santiago que, desde su condición inicialmente periférica, parece registrar a la distancia. Más aún, la propia fuerza gravitacional de la ciudad puede llegar a alterar las formas que la casa va tomado a lo largo de su desarrollo.

Solemos ver la ciudad y su crecimiento como contexto de la obra de arquitectura; algo que la preexiste y que la determina. Menos frecuentemente somos conscientes de cuánto una pieza arquitectónica puede ser factor clave en el desarrollo de un área urbana. Especialmente, cuando ella no es meramente un volumen aislado sino parte de una forma territorial.

ConSTTTUCIÓN DE LA PROPIEDAD Y RECONSTTTUCIÓN GEOGRáficA / Parte de la encomienda concedida por Pedro de Valdivia a Rodrigo de Araya, los terrenos ubicados entre el cerro San Cristóbal y el río Mapocho habían sufrido sucesivas subdivisiones durante los s. XVII y XVIII. A fines del s. XVIII la rinconada determinada por la falda del cerro, dos de sus puntillas y el río estaba dividida en una serie de propiedades de unas pocas hectáreas cada una. Corresponde a Francisco de Avaria ${ }^{3}$ el haber reunificado la propiedad a través de una serie de compras haciendo coincidir sus límites prediales con unos límites geográficos muy precisos, que hasta hoy lo hacen claramente identificable. Casado con Matilde Salamanca, Avaria dejó en herencia la propiedad a su sobrina huérfana Mercedes Contador, de quien actuaba como tutor, y construyó en ella una casa que formaría posteriormente parte de su dote ${ }^{4}$.

Es difícil reconstruir con exactitud lo que serían las características del área en la época ${ }^{5}$. En cualquier caso es probable que haya estado en parte plantado de frutales, como nogales y olivos, de los que existen registros explícitos en documentos posteriores. Lo Contador era en sus inicios una chacra suburbana que, a pesar de estar físicamente bastante cercana al centro, se percibía de facto, como una propiedad extramuros.

La entonces incipiente ciudad de Santiago bordeaba los 40.000 habitan-
THE BIG AND THE SMALL / Robin Evans opens his classic book Doors Figures and Passages (Evans, 1997) stating that ordinary things hide the most profound mysteries. The traces of the forms and the direction of the growth of a city can be perceived in an urban element as specific as a house ${ }^{2}$. Such forms of scaled interaction that enable us to recognize the traces of the greater in the smaller, and vice versa, constitute a very central part of the phenomena that architecture has had to deal with throughout history.

The Lo Contador House, located in what is today the borough of North Pedro de Valdivia, in Santiago, has almost miraculously resisted the passage of time and the growth of the city. Today, literally submerged in the urban texture of the neighborhood, the relationship that exists between it and the urban area that surrounds it is perhaps not readily apparent. Like so many Chilean rural houses, Lo Contador is the result of a long evolutionary process. This has depended on multiple historical factors, principally the owners and the form of productive exploitation. Nevertheless, it is not detached from the development processes of the city of Santiago which, from its initially peripheral condition, it appears to register at a distance. Furthermore, the gravitational pull of the city can alter the forms that the house takes throughout its entire development.

We tend to see the city and its growth as part of the context of architectural works; something that pre-exists and determines it. We are less frequently conscious of how much an architectural work can be a key piece in the development of an urban area, especially when it is not merely an isolated volume but part of a territorial form.

CONSTITUTION OF THE PROPERTY AND GEOGRAPHICAL RECONSTTTUTION / Part of the grant to Rodrigo de Araya by Pedro de Valdivia, the lands located between Mount San Cristobal and the Mapocho River were successively subdivided during the $17^{\text {th }}$ and $18^{\text {th }}$ centuries. At the end of the $18^{\text {th }}$ century, the area defined by the foot of the mountain, two of its points and the river, was divided into a series of properties of a few hectares each. The task of consolidating the property fell to Francisco de Avaria ${ }^{3}$ through a series of purchases, making the boundaries of the property coincide with some very precise geographical limits that make it clearly identifiable to this day. Married to Matilde Salamanca, Avaria bequeathed the property to his orphaned niece, Mercedes Contador, of whom he was guardian, and he built a house on it which would later be part of her dowry4.

It is difficult to accurately reconstruct the probable characteristics of the area at the time ${ }^{5}$. In any case, it is likely that it was partially planted with fruit trees such as walnuts and olives, of which there is specific mention in later documents. Lo Contador was initially an outlying farm which, despite being physically very near to the center, was in fact perceived to be a property outside the city limits.

The then incipient city of Santiago had close to 40.000 inhabitants and did not transcend the eastern barrier of Mount Santa Lucia until well into the $19^{\text {th }}$ century. The different plans drawn of it during the $18^{\text {th }}$ and 19th centuries ${ }^{6}$ therefore do not include the Lo Contador area. The 
' Los resultados de este artículo se deben a un largo trabajo de colaboración. Destaco los notables trabajos de los a lumnos del Taller de Investiga los alum sobre la casa de Lo Contador dirigido junto a Sergio Salazar el I semestr de 2004. Fundamental ha sido también el proyecto DIPUC La chacra Lo Contador: evolución de un edificio patrimonial.

${ }^{2}$ Alberti señaló en De Re Aedificatori que, en una suerte de paradójico intercambio de escalas, una casa pod verse como una ciudad y una ciudad como una casa.

${ }^{3}$ Según José Toribio Medina, Avaria sivió en la infantería y caballería siendo nombrado por Manuel de Salamanca teniente general y visitad de minerales. Manso de Velasco le nombró corregidor de Melipilla y Alcalde Mayor de Minas.

\begin{tabular}{l}
\hline${ }^{4}$ Francisco de Avaria era casado con \\
Matilde Salamanca y tenían ellos \\
mismos una propiedad en el área. \\
${ }^{5}$ El Plano de hijuelas y chácras entre \\
el cerro San Cristóbal y el río Mapocho \\
de Antonio de Lozada (1764), muestra \\
un sitio cercado como un huerto o una \\
viña en los terrenos de Lo Contador. \\
${ }^{6}$ Piénsese en los de Frezier, Mostardi \\
Fioretti y Ansart, publicados por Cas- \\
tedo en el resúmen de la historia de \\
Encina. Ellos registran los crecimientos \\
de la ciudad hacia el poniente, el sur \\
y el norte durante el s. XIX. Habrá que \\
esperar el plano del ejército de $1895-$ \\
1905 para ver el sector "La Contadora" \\
incluido en el plano de Santiago. \\
\\
${ }^{7}$ El puente fue construido bajo la \\
dirección del corregidor Zañartu entre \\
1767 y 1782, garantizando por más de \\
un siglo la comunicación entre ambas \\
riberas del río. Es derribado en 1888,
\end{tabular}

'The results of this article are due to prolonged collaboration. I specially highght the notable work of the students the Sergio Salazar during I semester of 2004 The DIPUC project, The Lo Contador Farm: evolution of a heritage building, has also been fundamental.

\section{Alberti stated in De Re Aedificatoria} that in a sort of paradoxical interchange of scales, a house could appe as a city and a city as a house.

${ }^{3}$ According to José Toribio Medina, Avaria served in the infantry and cavalry, and was appointed Lieutenant General and Mine Inspector by Manuel de Salamanca. Manso de Velasco ne Samed him the Mayor of Melipilla and Chief Inspector of Mines.

cisco de Avaria was married to Matilde Salamanca and they them-

\section{selves owned property in the area. \\ ${ }^{5}$ Antonio de Lozada's map (1764) of the estates and farms between Mount San Cristobal and the Mapocho River shows a property fenced in the manner of an orchard or a vineyard on the Lo Contador lands. \\ ${ }^{6}$ We are referring to those of Frezier Mostardi Fioretti and Ansart, published by Castedo in Encina's historical summary. They record the growth of the city to the west, the south and even the north during the $19^{\text {th }}$ century. But only the army's map of 1895-1905 in the map of Santaigo. \\ ${ }^{7}$ The bridge was built under the direction of Mayor Zañartu between 1767 and 1782, guaranteeing com- munications between both banks of the river for more than a century It was demolished in 1888 , year of the}

\section{publication of the work by Abel Rosales about the bridge \\ ${ }^{8}$ The grange is a interesting architec- tural system both from the constructive and functional points of view, which has not yet been properly studied. It would become more difficult to find one as the $19^{\text {th }}$ century progressed. Lo Contador shares architectural characteristics with roups such as to Matta lo Fontecita and the old houses of El Rosario. \\ ${ }^{9}$ The details of the initial state of the house can be deduced from the docu- ment describing the dowry of Mercedes Contador dated 1793, in which the house is described and assessed. \\ ${ }^{10}$ Raul Irarrazaval has highlighted this expansiveness of the house's space being prolonged through walls and passages in his works on granges in the central valley. This situation is visible in San José de El Carmen in El Huique.}

tes y no superará la barrera del Santa Lucía, hacia el oriente, hasta bien entrado el s. XIX. Los diversos planos que de ella se dibujan durante los s. XVIII y XIX ${ }^{6}$, no incluyen, por tanto el área de Lo Contador. La construcción del puente de Cal y Canto, relativamente contemporáneo con las compras de Avaria7, apoyó el difícil desarrollo de la ciudad hacia el norte, y facilitó las conexiones de Lo Contador con el centro de Santiago. Estas, y hasta un siglo y medio más tarde, se producían básicamente por el flanco norte de la propiedad, a través de un camino que atravesaba la actual zona de Bellavista.

El TRAZO DE LA ALQUERÍA / Es sobre estos terrenos que Francisco de Avaria construirá la casa de Lo Contador, desde entonces centro de gravedad de la propiedad. La casa seguirá el modelo de una alquería como lo hacen una serie de casas rurales contemporáneas en los alrededores de Santiago8: un solo cuerpo longitudinal de dos pisos, con corredores tanto en su cara norte como en su cara sur y escaleras de acceso que exceden el volumen del edificio. Los recintos del primer nivel -cuartitos y bodegas- estaban destinados a servicio, mientras las habitaciones principales se localizaban en el segundo.

La superposición de servicio y bodegas con habitaciones establece una relación frecuente en casas de campo europeas y que irá desapareciendo en Chile en la medida en que se constituyan patios de servicio y llaverías. Una sección longitudinal de Lo Contador muestra bien la forma en que los recintos de servicio se levantan del suelo lo mínimo posible, mientras las habitaciones del segundo piso alcanzan una altura mayor, acentuada en el volumen original por no existir cielos rasos: una suerte de piano nobile levantado sobre un podio sólido. La independencia de los dos pisos es bien notable ya que las bodegas -actual túnel- se conectaban directamente al camino de ingreso y al campo, mientras a las habitaciones se accedía desde los patios.

Por otra parte, el esquema constructivo de la alquería aparente en su corte transversal, muestra su original estructura: dos muros longitudinales de adobe conectados entre sí por elementos del mismo material (entre los cuales se localizan los cuartitos), sobre el cual se levantan los dos muros paralelos del segundo piso. Tanto el entramado de piso como la estructura de techumbre y las divisiones de las habitaciones del segundo nivel están construidas en madera. Estos últimos, aunque aparecen como muros, se construyen a la manera de una doble quincha, teniendo la virtud de conectar los muros longitudinales y no cargar el entramado de piso.

Muy pronto recibió la casa una adición hacia el oriente consistente en un recinto que alojaba dos lagares de piedra, lo que da testimonio de la importancia que las viñas deben haber adquirido en la propiedad a fines del s. XVIII y comienzos del s. XIX. Como en otras casas del período la cocina era un recinto independiente ubicado al norte ${ }^{9}$.

Siendo básicamente un volumen oriente-poniente, la casa parece haberse extendido a través de tapiales en el sentido norte-sur, configurando una trama de recintos que se extendía desde el cerro al río ${ }^{10}$. Ella se orientaba building of Cal y Canto Bridge, relatively contemporary to the purchases of Avaria ${ }^{7}$, aided the difficult development of the city toward the north and facilitated the connection of Lo Contador to the center of Santiago. Connections were basically along the northern flank of the property for the next century and a half, by means of a road that crossed what is now the Bellavista area.

THE DESIGN OF THE FARMHOUSE / It was on these lands that Francisco de Avaria would build the Lo Contador house, the center of gravity of the property from then on. The house would follow the model of a grange, as do a series of contemporary rural houses in the vicinity of Santiago ${ }^{8}$ : a sole two-storied longitudinal body with corridors both on its northern and southern facades and access staircases that exceed the volume of the building. The spaces on the first floor-small rooms and storerooms- were service areas whereas the main rooms were located on the second floor.

The superposing of service rooms and storerooms with bedrooms establishes a relationship frequently found in European country houses that begins to disappear in Chile as service courtyards and administration buildings begin to appear. A longitudinal section of Lo Contador illustrates very well the way the service areas are as low as possible whereas the second storey rooms are higher, accentuated in the original volume as there were no flat ceilings: a sort of piano nobile erected on a solid podium. The independence of the two floors is very notable as the storerooms - now the tunnel- are directly connected to the entrance roadway and the fields, whereas the rooms were entered from the courtyards.

Furthermore, the way the grange was built, evident in its cross-section, shows its original structure: two longitudinal adobe walls connected by elements of the same material (between which the small rooms are located) and on which the two parallel walls of the second floor are raised. Both the floor framework and the roof structure are built of wood, as are the divisions between the rooms on the second floor. Although the latter appear to be walls, they are constructed like a double latticework, having the virtue of connecting the longitudinal walls without burdening the floor framework.

An addition was soon made to the east of the house, consisting of a space that housed the stone wine presses, which is witness to the importance that the vineyards must have had on the property at the end of the $18^{\text {th }}$ and beginning of the $19^{\text {th }}$ centuries. Like in other houses of the period, the kitchen was an independent space located to the north ${ }^{9}$.

Being basically an east-west orientated volume, the house appears to have been extended by means of adobe walls in a north-south direction, making up a network of spaces that extends from the mountain to the river ${ }^{10}$. It was principally running northward, toward where the garden through which one arrived from Santiago was located. There is also evidence of a possible southern entrance through the small portico located in the main courtyard. 


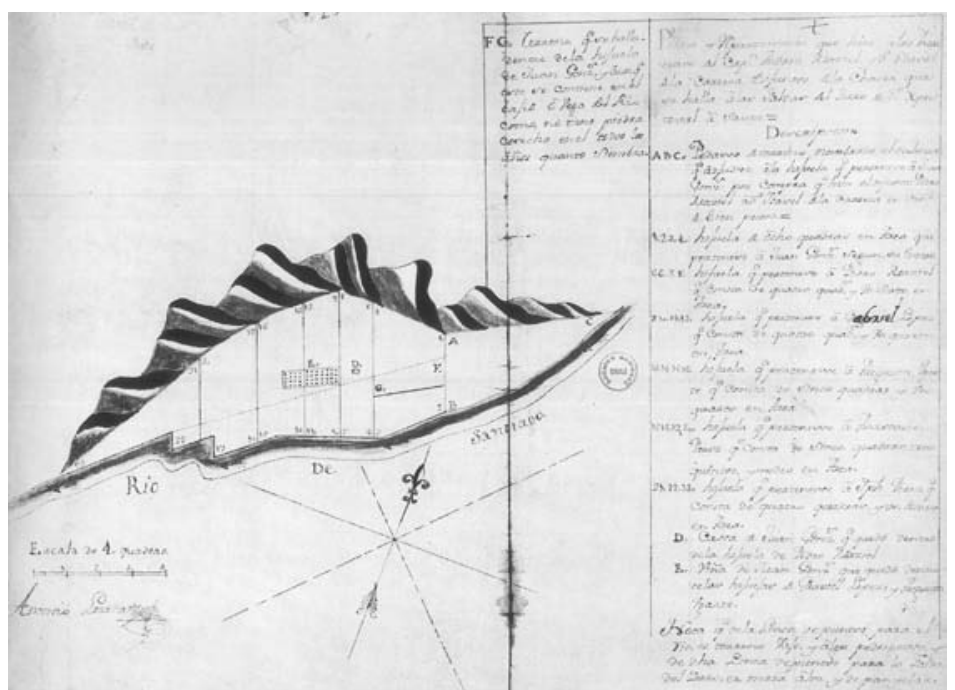

principalmente al norte, hacia donde se localizaba el jardín desde donde se llegaba desde Santiago. Hay testimonios también acerca de la posibilidad de entrar a través de un zaguancillo desde el sur donde se localizaba el patio principal.

Lo Contador representa la manifestación de un saber constructivo local que ha alcanzado una cierta madurez. Con muy pocos medios, básicamente adobes y maderas nativas, fue capaz de plantear soluciones que, aunque modestas en términos arquitectónicos, tenían una potencia derivada de sus dimensiones y de su escala territorial. La construcción de Lo Contador seguramente por parte de maestros de obra locales es contemporánea y contrasta con la llegada de una arquitectura culta, representada por la figura de Joaquín Toesca ${ }^{11}$ quien, en esos años está construyendo el palacio de La Moneda y la nueva fachada de la Catedral de Santiago.

De la ALQUERía AL PATIO / El desarrollo de la casa desde la primitiva alquería hasta la casa de patios que hoy conocemos, constituye su transformación fundamental. Ella está marcada por un cambio simultáneo en el uso de la casa que pasa, por voluntad de Mercedes Contador, desde una chacra suburbana a ser una casa de retiros. Para alcanzar esta condición había debido producirse un largo proceso, incluyendo el juicio de divorcio de Mercedes Contador de su marido Antonio de Hermida ${ }^{12}$. Más allá de los detalles anecdóticos de un matrimonio, aparentemente infeliz desde sus comienzos, interesa destacar el apasionado interés de ambos litigantes por conservar la chacra de Lo Contador entre sus bienes. Si Mercedes Contador ganó la batalla fue a costa de no pocas sesiones de otros bienes a favor de su marido. No es fácil reconstruir el proceso por el cual el patio alcanza su actual condición ${ }^{13}$. Sin embargo, para cumplir con sus nuevas funciones, y más temprano de lo que habitualmente se ha creído, la casa adquirió una capilla, un refectorio y unos cuartos de alojamiento. Capilla y refectorio se sitúan como dos cuerpos perpendiculares a la alquería y los cuartos de alojamiento en la actual crujía sur, probablemente en mas de una etapa. Simultáneamente se construyen los baños en el punto en que la acequia que cruzaba el patio pasaba bajo el cuerpo poniente. Junto al refectorio se instaló una nueva cocina. Para mediados del s. XIX corredores rodeaban completamente el patio $^{14}$. Es probable que la última zona en construirse hayan sido los recintos de la esquina sur-oriente del patio.

La extensión de la casa a partir del núcleo inicial de la alquería y la doble función a la que debió servir, dejan sus huellas en la estructura de la casa. La alquería y los volúmenes alrededor del patio podían funcionar con cierta independencia.

A la muerte de Mercedes Contador la casa fue heredada por don Diego Martínez Contador, quedando gravada por diversas obligaciones religiosas de las cuales su nuevo propietario procuró liberarla ${ }^{15}$. Hacia fines de siglo, mientras en Santiago Vicuña Mackenna impulsa sus reformas urbanas, se hace crecientemente importante la explotación de canteras en el cerro. Con excepción de la de la puntilla, estas deberán detenerse con la expropiación del cerro en 1917.
01 Plano de hijuelas y chácaras entre el cerro San Cristóbal y el rí Mapocho Autor Antonio Lozada. Dibujo publicado en Providencia: 100 años de la comuna. Ediciones de la Esquina Providencia: 10 Ltda. Santiago, Chile, 1997

01 Map of Estates and Farms between Mount San Cristóbal and the Mapocho River. Prepared by Antonio Lozada. Drawing published in Providencia: 100 años de la comuna. Ediciones de la Esquina Ltda. Santiago, Chile, 1997
La tRANSFormación DE COMIENZOS DE SIGlo / Diego Martínez muere en 1900, heredando la casa don Luis Martínez, quien la habita hasta su muerte en $1955^{16}$. La existencia de un proyecto de remodelación fechado en 1915 y firmado por el arquitecto Ramón Fehrman Martínez ${ }^{17}$, tal vez pariente de la familia, da indicaciones importantes para comprender algunas características de la actual casa. Fehrman Martínez pertenecía a una de las primeras generaciones de arquitectos formados en Chile y su intervención sobre la casa da cuenta de las complejas relaciones establecidas con la arquitectura colonial y rural. El proyecto contemplaba la construcción de un torreón en el ángulo norponiente de la casa y la elaboración de las fachadas sur y poniente. Para ello, incorporando elementos estilísticos clásicos y del barroco español, se regularizaban las ventanas, se incluían balcones y se abría una nueva puerta de la capilla al exterior. Un nuevo cierro de ladrillo al poniente reemplazaba, en parte, al antiguo de adobe y una nueva escalera de acceso se situaba en el encuentro de este con la casa, cuyo primer nivel se revestía en piedra.

El proyecto de Fehrman se construyó muy parcialmente y con variantes. La fachada sur, simétrica y con elementos clásicos, que incluye el traslado del zaguán, y muy probablemente la apertura de nuevas ventanas hacia el río, es acaso su huella más visible. También la construcción de cielos rasos, las puertas más elaboradas y complejas del flanco sur del patio y la abundancia de elementos de piedra, parecen provenir de esta reforma. Por su parte, el pasillo del segundo piso de la alquería, recordando a Robin Evans, constituye un elemento aparentemente inocente pero que ya denuncia un modo bien diverso de entender la planta de la casa ${ }^{18}$.

Pero acaso la transformación más substancial ocurrida en este momento en la casa es que ella comienza a mirar al sur, al río y a Providencia. Tal giro queda subrayado por el establecimiento de la fachada sur como la principal y el abandono del proyecto de la fachada poniente. El es coincidente con la decidida expansión de Santiago hacia el oriente producida desde comienzos del s. XX. La llegada a la casa comienza a producirse cada vez más frecuentemente desde Providencia, a través de un precario puente peatonal situado frente a la antigua calle de Montolín.

LA CASA Y EL BARRIO / Las actividades agrícolas parecen haberse ido deteriorando, entre otros factores por problemas con los derechos de agua y el regadío. La explotación de la piedra se reducía sólo a la cantera de La Puntilla. La presión de una ciudad en expansión y la construcción de un puente vehicular frente a la recientemente abierta calle de Pedro de Valdivia Norte y posteriormente frente a Nueva de Lyon sellarán el destino inmobiliario de la chacra.

La población Pedro de Valdivia Norte, primer loteo en el área ${ }^{19}$, se situaba entre la prolongación de la calle del mismo nombre hasta la falda del San Cristóbal y la calle El Cerro, teniendo como eje central Padre Letelier. Ella se plantea como una suerte de barrio modelo, con un núcleo central provisto de una plaza, un conjunto de edificios de tres pisos, locales comerciales y una parroquia. Sus calles ligeramente curvilíneas resolvían el trazado 
"Toesca permanece en Chile las dos últimas décadas del s. XVIII introduciendo no sólo nuevas concepciones y un nuevo y un nevo lenguje aruitectónico. as cons-

${ }^{12}$ Este juicio se desarrolla entre 1818 y 1820.

13 Las casas rurales de adobe eran continuamente reparadas y modifcadas. Las huellas de tales modificaprecisa. Irregularidades en los techos presentes en las fotografías de hasta mediados dels $x X$ posteiomente regularizadas, dan cuenta en Lo regularizadas, dan cuenta en Lo Contador de las complejidades
este proceso de crecimiento.

14 Un contrato de pinturas de 1839-40 nos permite estar ciertos de que, para entonces, el patio ya tructivas ligadas a la albañilería. ciones frecuentemente desaparecen haciendo muy difícil su reconstitución

estaba completamente rodeado de
corredores. Por entonces se construye
también el altar de la capilla.
15 Mercedes Contador muere en
el año 1864, después de haber
conseguido autorización oficial para
Lo Contador como casa de retiros.
En su testamento gravó la casa con
la obligación de realizar dos corridas
al año para 300 personas cada una.
Los gastos debían solventarse con
las ganancias de la producción de
la chacra. Diego Martínez Contador,
realizó una subdivisión del terreno y
acudió a diversas instancias eclesiás-
ticas para demostrar la inviabilidad
de tales obligaciones. En la década
de 1890, y por diversas circunstan-
cias, no se realizan retiros.
16 Aparentemente Luis Martínez
aprovechó la estructura de la casa
para vivir independientemente en
la zona de la alquería, mientras el

resto de la familia lo hacía en el cuerpo sur.

17 Ramón Fehrman Martínez nacido en 1876 era hijo de Juan Eduardo Fehrman. Estudió arquitectura en la Ver artículo de Hernán Rodríguez en el diario El Mercurio, 21/10/1983.

18 Fehrman detalla esa zona correspondiente a lo que fue el escritorio de Luis Martínez en su proyecto.

19 Luis Martínez vende con fines inmobiliarios 30 hectáreas de su propiedad en 1938 . El puente Pedro de Valdivia se construye en 1939 . provión de Pedro prolongación de Pedro Norte inaugura un nuevo acceso al cerro en el punto en que se encuent con su falda. Anteriormente tal acceso se producía más al poniente. Universidad de Chile a fines de siglo.

Lo Contador represents the expression of local building knowledge that had achieved a certain maturity. With very few means, basically adobe and native lumber, it was capable of proposing solutions which, although they were modest in architectural terms, had power derived from their dimensions and territorial scale. The construction of Lo Contador, most probably by local builders, is contemporary and contrasts with the arrival of a cultured architecture represented by the person of Joaquin Toesca ${ }^{11}$, who at that time was building The Moneda Palace and the new façade of the Santiago Cathedral.

From tHe FARMHOUSE TO THE COURTYARD / The development of the house from the original farmhouse to the house with courtyards that we now know is a fundamental transition. This is marked by a simultaneous change in the use of the house that was transformed, through the wishes of Mercedes Contador, from a suburban farmhouse to a place for retreats. Achieving this must have been a lengthy process that included the divorce suit between Mercedes Contador and her husband Antonio de Hermida ${ }^{12}$. Beyond the anecdotal details of a marriage, apparently unhappy from the beginning, it is interesting to note the passionate interest of both parties to the suit in keeping the Lo Contador grange among their assets. If Mercedes Contador won the battle, it was at the cost of ceding numerous other properties to her husband.

It is not easy to reconstruct the process by which the courtyard achieved its present condition ${ }^{13}$. However, in order to comply with its new functions, and earlier than is generally believed, the house acquired a chapel, a dining hall and some lodging rooms. The chapel and the dining hall are situated as two bodies perpendicular to the farmhouse, and the lodgings in the present southern corridor were probably built in more than one stage. Simultaneously, the bathrooms were built at the point where the steam that crossed the courtyard passed beneath the western wing. The new kitchen was built next to the dining hall. Toward the middle of the $19^{\text {th }}$ century, corridors completely surrounded the courtyard ${ }^{14}$. It is probable that the last spaces to be built were those at the south-east corner of the courtyard.

The extension of the house from the initial nucleus of the farmhouse and the dual function that it served have left their marks on the structure of the house. The farmhouse and the volumes around the courtyard could function with a certain independence.

After the death of Mercedes Contador, the house was inherited by Diego Martinez Contador, but it was burdened by various religious obligations from which its new owner attempted to free it ${ }^{15}$. Toward the end of the century, while Vicuña Mackenna promoted his urban reforms in Santiago, the exploitation of quarries on the mountain became increasingly important. With the exception of La Puntilla, these had to cease after the expropriation of the mount in 1917.

The Transformation at the beginning of the century / Diego Martinez died in 1900 and Luis Martinez inherited the house and lived there until his

\section{Toesca remained in Chile until the last decades of the $18^{\text {th }}$ century introducing not only new concepts in a new architectural language, but also
new construction techniques linked new constructio \\ 12 This lawsuit took place between 1818 and 1820. \\ 13 Rural adobe houses were continu- ally repaired and modified. The traces of such modifications frequently disappear, making their precise recon- struction very difficult. Irregularities in the roofs present in photographs through the mid-20 th century and ter Contador to the complexities of this growth process. \\ ${ }^{14}$ A painting contract of $1839-1840$ enables us to be certain that by then the courtyard was already completely surrounded by corridors. The chapel's}

altar was also built at that time.

15 Mercedes Contador died in 1864 Ister having received official aut atter having received offia ar tion for Lo Contador to become a place for retreats. In her will she encumbered the house with the obligation to hold two revivals per year for 300 people each. The expenses had to be defrayed by the profits from the farm Diego con property and appealed to several ecclesiastical authorities to prove that such obligations were not viable. In the decade of the 1890 s, no retreats were held for several reasons.

\section{${ }_{16}$ Apparently, Luis Martinez took} advantage of the structure of the house to live independently on the left side while the rest of the family lived in the southern sector.

17 Ramon Fehrman Martinez, born in 1876, was the son of Juan Eduardo

\section{Fehrman. He studied architecture at the University of Chile at the end of the century. See article by Hernan Rodriguez in the El Mercurio newspa- per, 21/10/1983. \\ 18 Fehrman describes this area, corre- sponding to the study by Luis Martinez in his project. \\ 19 Luis Martinez sold 30 hectares of his property for real estate speculation in 1938. The extension of North Pedro de Valdivia inaugurated a new access to the mountain at the point where it meets its base. Prior to that, this access was found further west.}

death in $1955^{16}$. The existence of a remodeling project dated 1915 and signed by the architect Ramon Fehrman Martinez ${ }^{17}$, perhaps a relative of the family, gives important insights into understanding some characteristics of the existing house. Fehrman Martinez belonged to one of the first generations of architects trained in Chile and his work on the house reflects the complex relationships established with colonial and rural architecture. The project contemplated building a tower at the northwestern angle of the house and improving the southern and western facades. This was done by incorporating classical and Spanish baroque elements, the windows were standardized, balconies were included and a new door placed that opened the chapel to the outside. A new brick closure on the west side partly replaced the former adobe one and a new access staircase was located where this met the house, whose first floor was covered by stone.

Fehrman's project was built only partially and with variations. The southern facade, symmetrical and classical, includes the relocation of the portico and very probably the opening of new windows toward the river, perhaps its most visible sign. The construction of flat ceilings, the more elaborate and complex doors on the southern flank of the courtyard and the abundance of stone elements appear to derive from this reform. Furthermore, the passage on the second floor of the house, in the style of Robin Evans, constitutes an apparently innocent element but which already betrays a very different way of understanding the plan of the house ${ }^{18}$.

But perhaps the most substantial transformation that occurred in the house at that time was that it began to look toward the south, toward the river and Providencia. That switch is highlighted by making the southern façade the main one and abandoning the western façade project. This coincides with the decided eastward expansion of Santiago from the beginning of the $20^{\text {th }}$ century. The house is approached with increasing frequency from Providencia over a precarious pedestrian bridge located in front of the former El Montolin road.

THE HOUSE AND THE BOROUGH / The farming activities appear to have begun to deteriorate due, among other factors, to problems with irrigation and water. Rock extraction was reduced to just the La Puntilla quarry. The pressure of a city in expansion and the construction of a vehicular bridge in front of the recently opened North Pedro de Valdivia Street, and later Nueva de Lyon, would seal the real estate fate of the house.

The North Pedro de Valdivia borough, the first real estate development in the area ${ }^{19}$, was located between the extension of the road with the same name, the base of Mount San Cristobal and El Cerro Street, Padre Letelier being its central axis. It was promoted as a sort of model borough with a central nucleus consisting of a square, a group of three-storied buildings, shops and a parish church. Its slightly curved streets laid out roadways on a triangular site and appeared to be more natural in a neighborhood that sought the protagonism of vegetation. A significant part of this development was built on terrain that was part of the course 

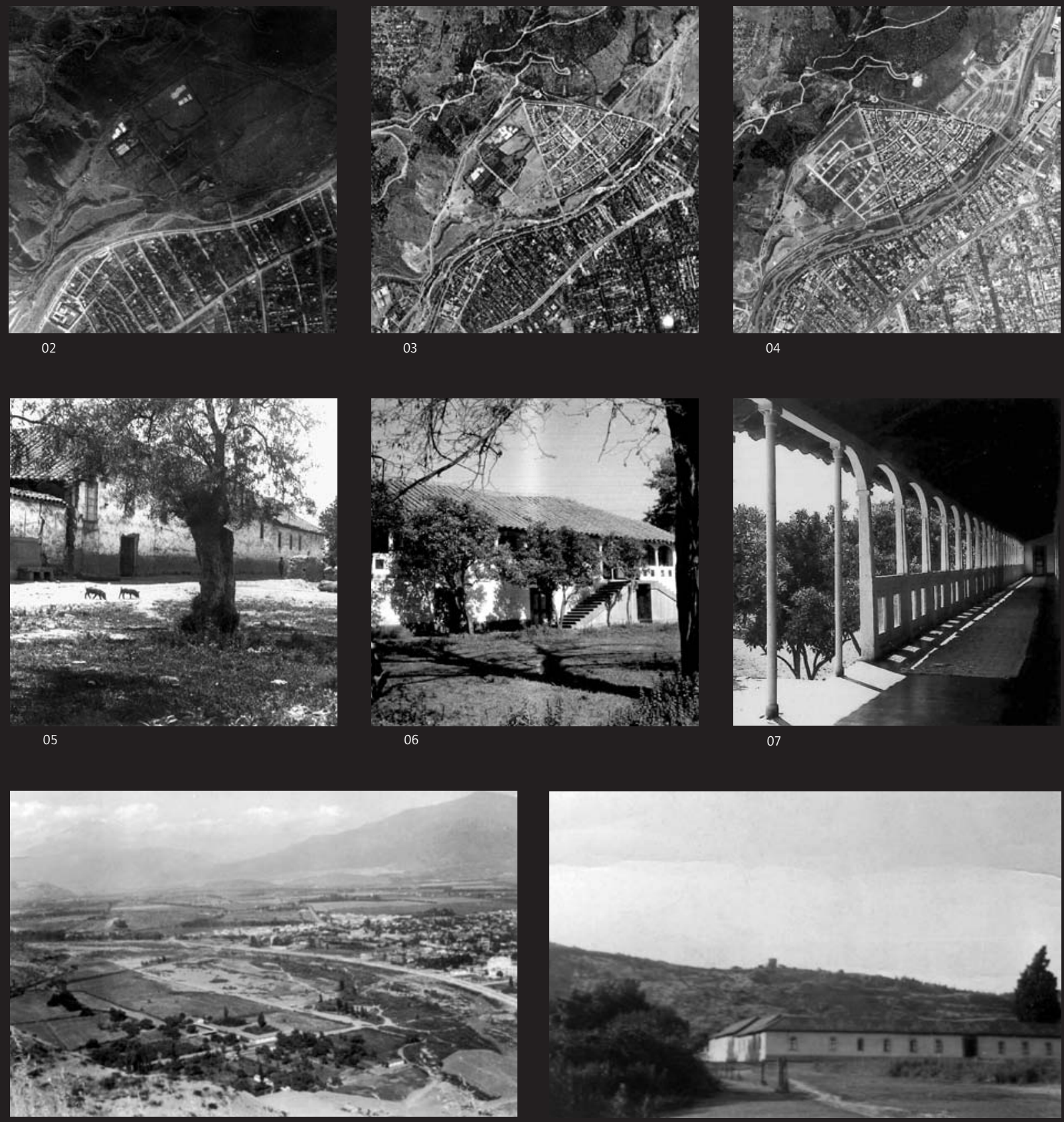

09
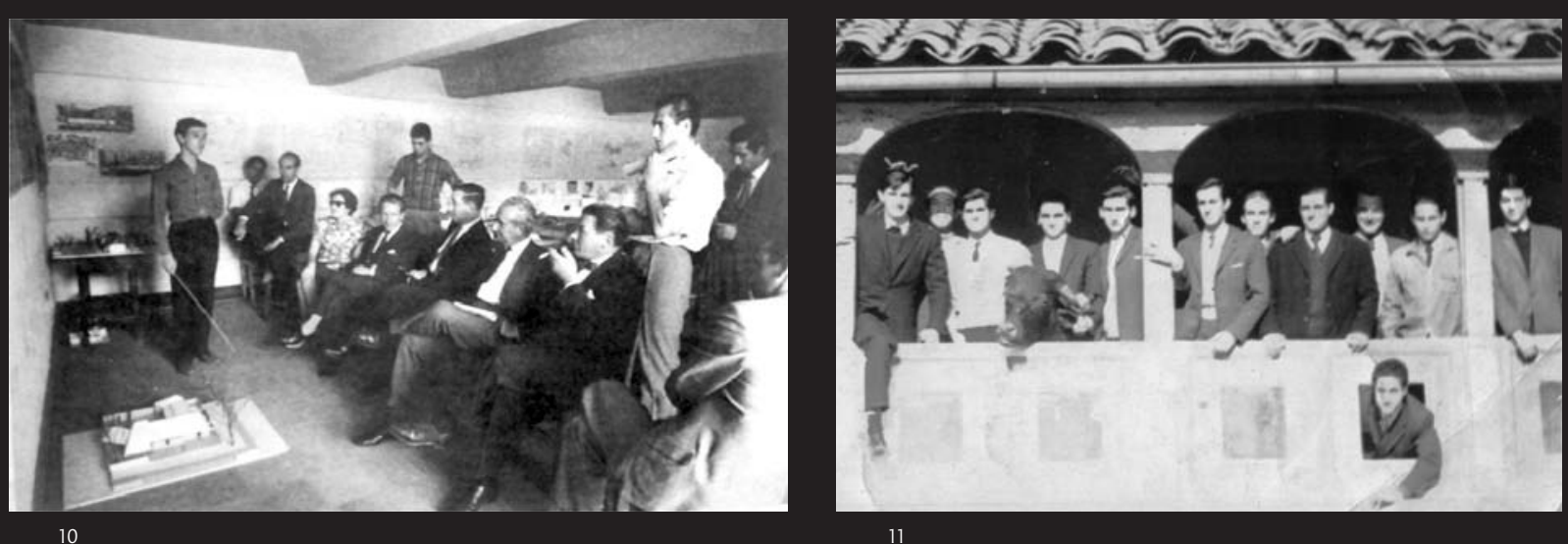


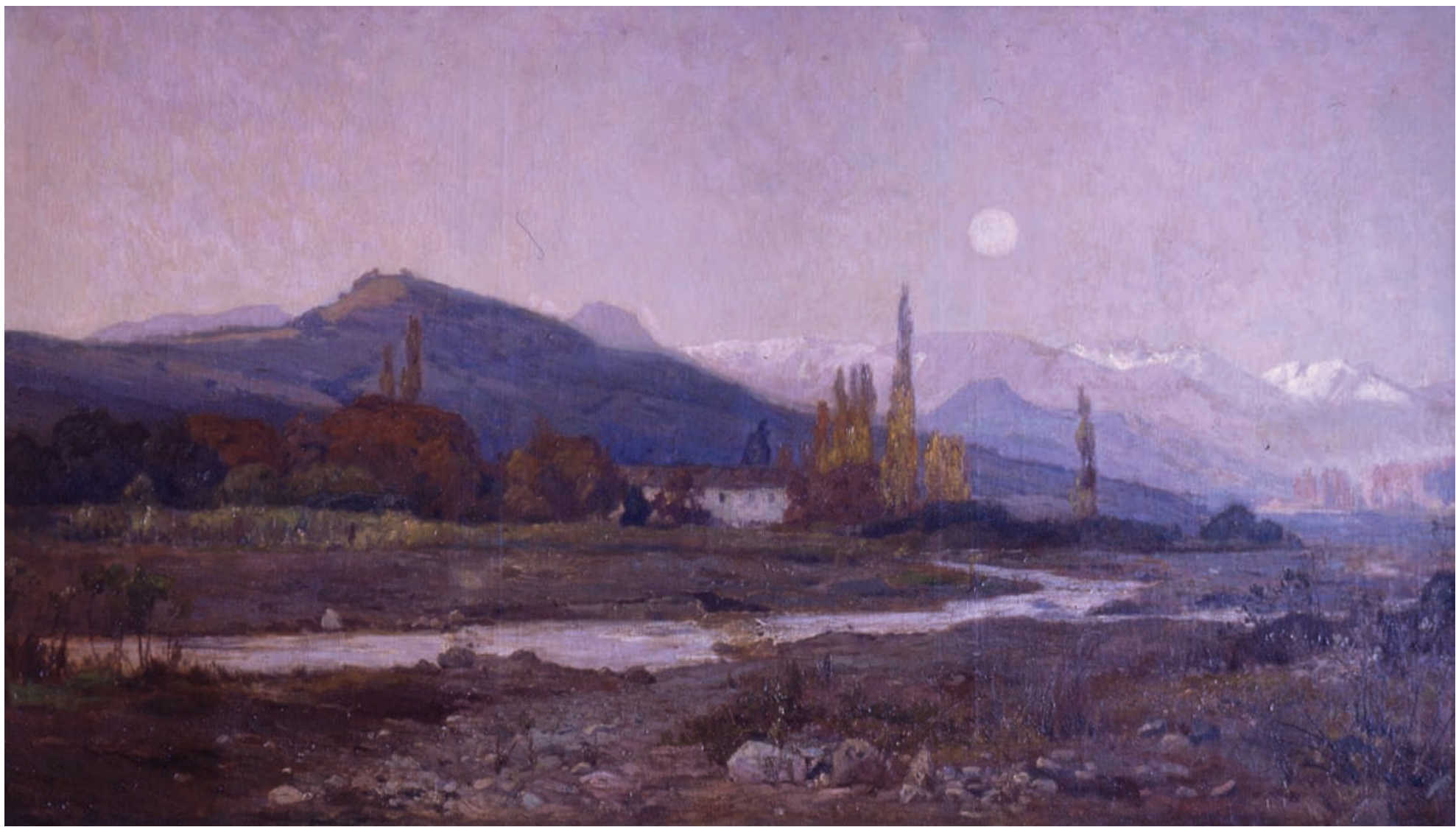

12

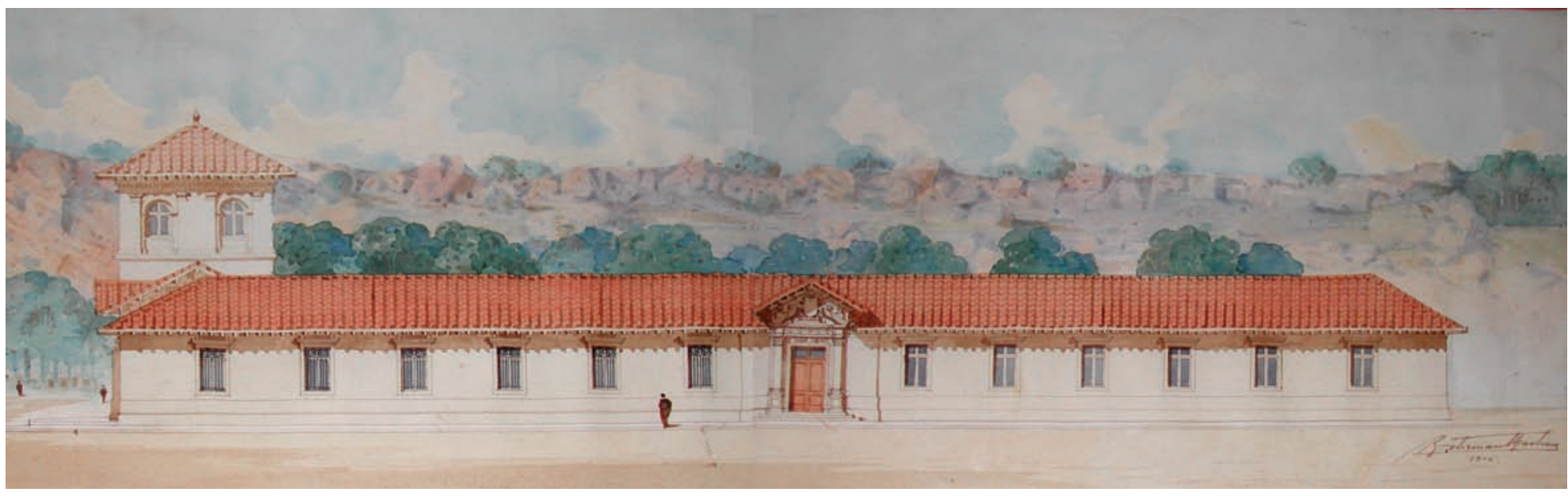

13

02 Fotografía aérea hacia 1943. Instituto Geográfico Militar

03 Fotografía aérea hacia 1954. Instituto Geográfico Militar

04 Fotografía aérea hacia 1961. Instituto Geográfico Militar

05 Fotografía de la casa de Lo Contador. c. 1900. Autor desconocido.

Archivo Fotográfico del Museo Histórico Nacional, Santiago de Chile

06 Fotografía hacia 1940 de la fachada norte de la alquería. Autor desconocido.

En Amenabar, Larach, Guerrero "Lo Contador: Un Nuevo Destino." Tesis (arq) PUC. Santiago, Chile, 1975

07 Fotografía hacia 1940 del corredor norte de la alquería. Autor Idem anterior

08 Vista desde el cerro San Cristóbal. La fotografía es posible datarla debido a que se aprecia el Teatro Oriente del año 1937 y aún no se ha construido el puente Pedro de Valdivia de 1938. Autor desconocido. Archivo de Originales,

Facultad de Arquitectura, Diseño y Estudios Urbanos, PUC, Santiago, Chile

09 Fotografía hacia 1937 del volumen sur de la casa Lo Contador. Autor Idem anterio

10 Exposición proyecto de título. Al centro observan Sergio Larraín García-Moreno y Jorge Larraín. Autor desconocido.

En Krebs, Ricardo. Historia de la PUC: 1888 - 1988. Ed. Universidad Católica de Chile, 1994

11 Fotografía de un grupo de alumnos del cuarto año. 1962. Autor desconocido. Colección privada Rodrigo Correa

12 Hora Solemne, óleo de Alberto Valenzuela Llanos 1908, colección Club de la Unión

13 Elevación sur. Proyecto de remodelación de 1913 del arquitecto Ramón Fehrman Martínez. En Centro de

Información y Documentación Sergio Larraín García Moreno. El proyecto dibujado se realiza parcialmente e incluía

un torreón en la esquina norponiente
02 Aerial photograph around 1943. Military Geographic Institute

03 Aerial photograph around 1954. Military Geographic in

04 Aeriat phot

05 Photograph of the Lo Contador house. Around 1900. Photographer unknown

Photographic Archives of the National Historical Museum, Santiago, Chile

06 hotograph around 1940 of the north façade of the house. Photographer unknown. At Amenabar, Larach,

Guerrero "Lo Contador: Un Nuevo Destino." ("Lo Contador: A new destiny"). Thesis (file) PUC. Santiago, Chile, 1975 07 Photograph around 1940 of the northern corridor of the house.

08 View from Mount San Cristóbal. The photograph can be dated because one can see the Teatro Oriente of 1937 and the Pedro de Valdivia Bridge of 1938 has not yet been built. Photographer unknown. Original Archives. School of Architecture, Design and Urban Studies, PUC, Santiago, Chile.

09 Photograph around 1937 of the southern area of the Lo Contador house.

10 Degree project presentation. In the center we can see Sergio Larraín García-Moreno and Jorge Larraín

Photographer unknown. In Krebs, Ricardo. Historia de la PUC: 1888 - 1988, Ed. Catholic University of Chile, 1994

11 Photograph of a group of fourth-year students. 1962. Photographer unknown. Private collection of Rodrigo Correa.

12 Solemn Hour; oil painting by Alberto Valenzuela Llanos 1908, Club de la Unión Collection

13 Southern facade. 1913 Remodeling project by the architect Ramón Fehrman Martínez. In Center of Information

and Documentation Sergio Larraín Gracia Moreno. The project was built in part and included the tower on the north-west corner. 


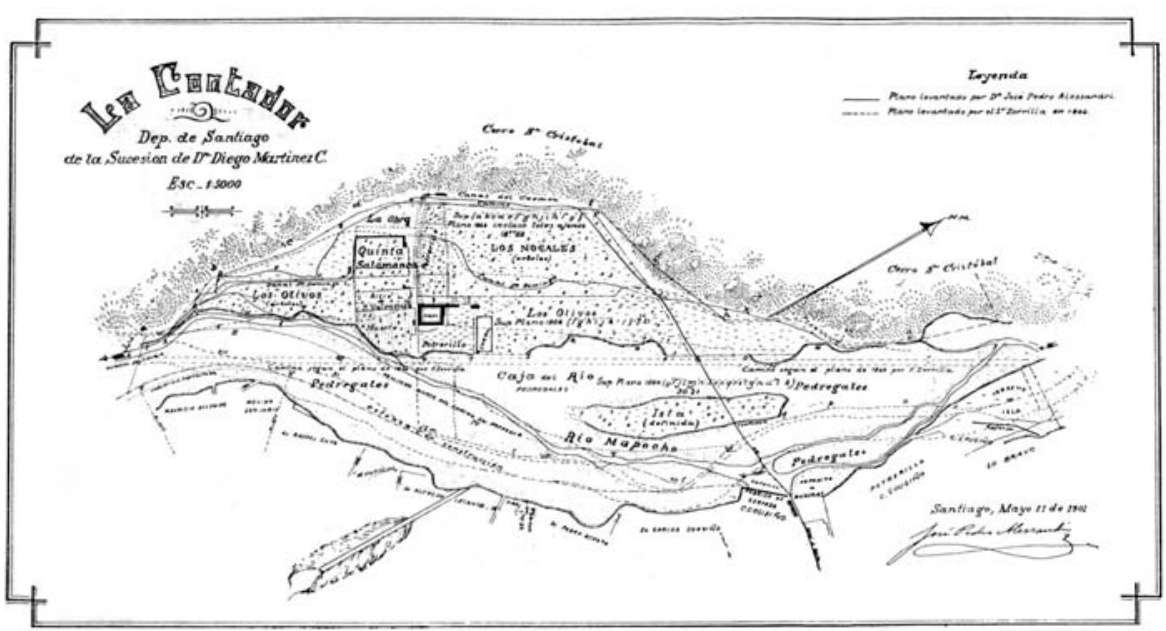

14

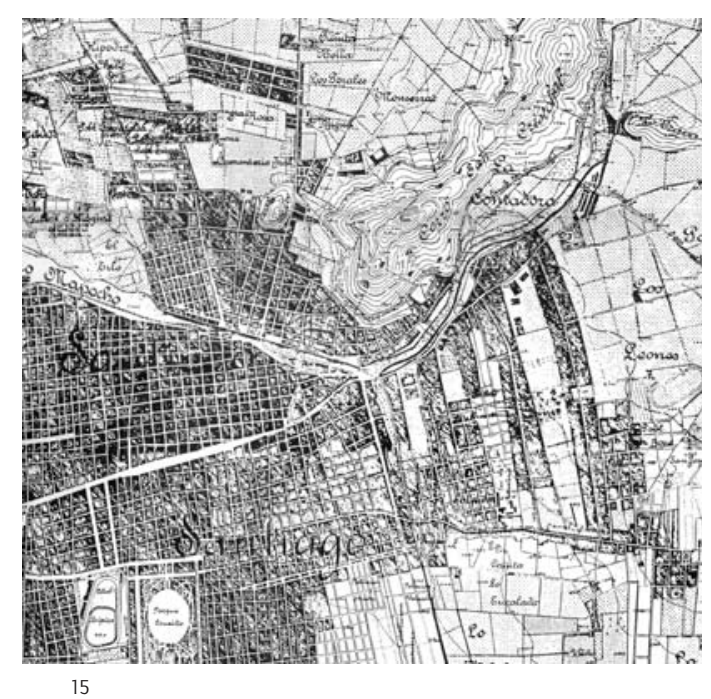

15 de vías en un terreno triangular y aparecían más naturales en una urbanización que buscaba un protagonismo de la vegetación. Parte significativa de esta urbanización se hizo en terrenos que pertenecían al curso del río, por lo que los esfuerzos de urbanización e incluso de construcción de las casas no fueron pocos. La actual calle Los Conquistadores, el principal eje de conexión oriente-poniente, prácticamente calcó el trazado del antiguo camino agrícola que uniendo las dos puntillas recorría en forma rectilínea el borde del antiguo cauce del río.

A partir de esta primera urbanización se completan posteriormente las de los sectores oriente y poniente. El hecho de que el sector poniente de la chacra estaba, a excepción de unas cuantas casas junto al río, prácticamente sin urbanizar a fin de los años cincuenta, permite a Sergio Larraín sugerir dicho sector para instalar allí el nuevo campus que la Universidad Católica deseaba construir. Tal posibilidad no prosperó frente a la opción de la chacra San Joaquín, mucho mayor en superficie aunque peor localizada desde un punto de vista urbano. La insistencia y la gestión personal de Larraín hicieron que se adquiriera la casa para instalar la Facultad de Arquitectura. El mismo adquirió la antigua casa de administración y el resto del lote ofrecido por la sucesión de don Luis Martínez ${ }^{20}$.

Tal adquisición produjo una modificación en la urbanización aprobada para entonces en la municipalidad, suprimiéndose una calle propuesta entre la casa principal y la de administración. Se generó así la larga manzana entre El Comendador y Los Navegantes. Esta se suma así a un tejido caracterizado por una peculiar forma de desarrollo del manzanero, con calles más largas en el sentido oriente-poniente, paralelas al río. Un sector integrado pero muy discernible dentro de la trama urbana de Providencia. Tal estructura contradice la antigua división norte-sur de las chácaras adquiridas por Avaria, de la que la casa y sus extensiones formaban parte, como si la conexión con el centro, y el sentido de la expansión de la ciudad al oriente siguiendo el curso del río hubiesen sido la fuerza dominante. De LA CASA AL CAMPUS / Desde que la casa fuese ocupada por la universidad, no ha sufrido transformaciones substanciales. El decanato y dirección de la escuela se instalaron en el cuerpo sur, que había pasado a ser el acceso principal de la casa. Los restantes recintos se ocuparon básicamente como aulas y talleres. La antigua cocina, posteriormente cochera se constituyó en casino, hasta su demolición con la construcción de la nueva biblioteca, recuperando algo de su sentido original. Alrededor de la casa se instalaron una serie de construcciones supuestamente provisorias, de un piso y en estructura metálica, algunas de las cuales aún permanecen. Estas se utilizaron para talleres de arquitectura o arte, aulas o dependencias administrativas $^{21}$. A fines de la década de los ochenta se construyen dos edificios de tres pisos en los flancos norte y oriente de la casa como parte de un plan mayor que apuntaba a cerrar un volumen en $\mathrm{L}$ alrededor de la casa ${ }^{22}$. Dicha iniciativa no se completó. En cambio, el nuevo edificio de la biblioteca de Teodoro Fernández, Cecilia Puga y Smiljan Radic se desarrolla paralelamente a la antigua alquería enfatizando el sentido oriente-poniente y apuntando al centro de la manzana. La adición de la antigua casa de administración, adquirida por la universidad el año 2000, ha enfatizado aún más dicho sentido, prolongando un vacío en torno al cual pivotea todo el campus, desde lo que fue el antiguo jardín de la alquería hasta el jardín de la casa de Sergio Larraín: el antiguo trazo oriente-poniente dibujado por la primera alquería que se fue prolongando hasta unirse con la casa de administración, vuelve a repetirse consolidando nuevamente lo que fue el acceso antiguo a la casa ${ }^{23}$.

La frecuencia con que Lo Contador fue pintado habla de su singularidad como paraje. Un dibujo de Rugendas de mediados del siglo XIX muestra la presencia imponente de la cordillera en el paisaje abierto por el río. Valenzuela Llanos retrató el lugar en múltiples ocasiones y solía acudir a pintar allí con sus alumnos ${ }^{24}$. Anclada al territorio que la rodeaba, a través de muros huertos y patios, la casa, formaba parte integrante de tal paraje y en algún modo lo constituía ${ }^{25}$. Contraída en sí misma como toda rinconada y a la vez parte de la complejidad del valle de Santiago: el cerro, la ciudad y la cordillera a la distancia.

El proceso a través del cual la chacra Lo Contador deviene al barrio Pedro de Valdivia Norte y con este, parte constituyente de la ciudad de Santiago, habla precisamente de la complejidad y la riqueza de esas relaciones oscilantes entre escalas diversas que tan fuertemente caracterizan a aquellos bienes que la arquitectura puede ofrecer a la ciudad. ARQ

\section{Bibliografía}

Amenabar, Pilar; Guerrero, Francisco; Larach, Carmen Gloria. Lo Contador un nuevo destino, Proyecto para optar a título de arquitecto. Pontificia Universidad Católica de Chile, 1975. / Castedo, Leopoldo; Encina, Francisco. Resumen de la historia de Chile. Editorial Zigzag, Santiago, 1954. / Evans, Robin. Translation from drawing to building and other essays. MIT Press, Cambridge, 1997. / Irarrázaval, Raúl. La casa patronal. Santiago, 1969. / Lama, Antonio Campus El Conquistador en revista ARQ 8, Nov 1983, pág. 10-12 / Larraín, Carlos J. Las Condes. Nascimiento, Santiago, 1952. / Meza, Fernán. Lo Contador. Seminario de título, Universidad de Chile, 1961. / Palmer, Montserrat. La comuna de Providencia y la ciudad jardín. Pontificia Universidad Católica de Chile, Facultad de Arquitectura y Bellas Artes, Santiago, 1984. / Rosales, Abel. Historia y tradiciones del puente de Cal y Canto. Manuel A Mujica, Ed. Imprenta Estrella de Chile, Santiafo, 1888.

44 Contador. Plano de la sucesión de don Diego Martínez 1901. Autor José Pedro Alessandri 15 Santiago: Plano del Ejército 1895-1905. Instituto Geográfico Militar 
20 Eduardo Frei Montalva participó en las negociaciones como a en las ne co como abogado y la venta se realizaron en 1958 . traslado de la Facultad en 1959.

${ }^{21}$ La forma de dichas construccione derivan del proyecto de título del arquitecto y profesor Horacio Borgheresi quien fuera decano de la Facultad entre 1967 y 1969.

22 Tal iniciativa estaba en buena parte basada en el proyecto de título que Antonio Lama había realizado propósito del desarrollo del campus ecto fue publicado en la revista $A R Q$ ese mismo año.

${ }^{23}$ Paralelamente, la conexión con e centro vuelve a consolidarse por la falda del cerro en lugar de realizase por Providencia.

24 Nemesio Antúnez, rememorando el nacimiento de su vocación de pintor, hablaba de las salidas a Lo Contador a hacer acuarela del natu- ral con el profesor Ignacio Baixas, antes de que la casa fuera adquirida por la univicic pundó funcionará por a rá por algún tiempo en el campus y el mismo construirá su casa en el barrio.

${ }^{25}$ La casa fue declarada Monumento Nacional en 1974.
${ }^{20}$ Eduardo Frei Montalva participated in the negotiations as the family's lawyer The sale promise and the sa took pace in 1958 . The School move to its new location in 1959

${ }^{21}$ The shape of those buildings cam from the degree project of Horacio Borgheresi, architect and professor who was dean of the School betwe 1967 and 1969.

22 That initiative was based, to a great extent, on the degree project designed by Antonio Lama for campus development in 1983. The project was published in ARQ Magazine that same year.

${ }^{23}$ At the same time, the connection to downtown is once again consolidated along the foot of the mountain instead of from Providencia.

${ }^{24}$ Nemesio Antunez, recalling the birth of his vocation as a painter. talked about the excursions to 10 talked about the excursions to Lo
Contador. to paint water colors of the original house with professor Ignacio Baixas before the house was purchased by the university. Taller 99 , which founded functioned on the campus

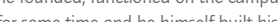
mself built his

${ }^{25}$ The house was declared a National Monument in 1974. of the river. As a result, considerable effort was put into the urbanization and even the construction of the houses. Los Conquistadores Road, the main east-west road, practically traced the route of the old farm road which ran along the former bed of the river in a straight line, uniting the two ends of the mountain.

The eastern and western sectors were completed after this first development. The fact that the eastern sector of the farm was virtually undeveloped at the end of the fifties, except for a few houses beside the river, allowed Sergio Larrain to suggest that sector for the new campus that the Catholic University wanted to build. Using the San Joaquin Farm was not a possibility, albeit it was much greater in area, but not as well located from an urban point of view. The insistence and the personal efforts of Larrain resulted in the purchase of the house to be used for the School of Architecture. He himself bought the former administration house and the rest of the property offered by the succession of Mr. Luis Martinez ${ }^{20}$. This acquisition caused a modification in the urbanization approved until then in the municipality, eliminating a proposed road between the main house and the administrative building. The long block between El Comendador and Los Navegantes was thus created. This then became part of a peculiar network characterized by a strange form of block development with longer roads in the east-west direction parallel to the river, an integrated but very noticeable sector within the urban network of Providencia. This structure contradicts the former north-south division of the farms acquired by Avaria, of which the house and its extensions were a part, as if the connection to the center and the direction of the expansion of the city eastwards, following the course of the river, had been the predominant force.

FROM HOUSE TO CAMPUS / The house has not undergone substantial transformations since it was taken over by the university. The dean's office and the school's management were installed in the southern wing, which had become the main access to the house. The remaining spaces were used mainly as classrooms and workshops. The former kitchen and then coach-house became the cafeteria until it was demolished for the construction of the new library, recovering some of its original meaning. A series of supposedly provisional one-storey metallic-structure buildings were installed around the house, some of which still exist. These were used as architecture or art workshops, classrooms or administrative offices $^{21}$. At the end of the 80 's, two three-storey buildings were built on the northern and eastern flanks of the house as part of a master plan that aimed at closing an L-shaped volume around the house ${ }^{22}$. That initiative did not go through. Instead, the new library building by Teodoro Fernandez, Cecilia Puga and Smiljan Radic stands parallel to the former farmhouse, emphasizing the east-west direction and pointing toward the center of the block. The addition of the former administration house, acquired by the university in 2000 , has emphasized that direction even more, prolonging the void around which the entire campus pivots, from what used to be the former garden of the house to the garden of Sergio Larrain's house: the former east-west direction, set out by the first house that got longer until it reached the administration house, is once again repeated, consolidating what used to be the former entrance to the house $\mathrm{e}^{23}$.

The frequency with which Lo Contador was painted speaks of the singularity of the place. A drawing by Rugendas from the mid-nineteenth century shows the imposing presence of the Andean mountain range in the landscape opened by the river. Valenzuela Llanos painted the place on many occasions and used to go there to paint with his students ${ }^{24}$ Anchored in the territory that surrounds it, through walls, orchards and courtyards, the house was an integrating part of that landscape and to a certain extent comprised $i^{25}$. Looking in upon itself, like every corner, and at the same time part of the complexity of the Santiago Valley: the mountain, the city and the mountain range in the distance.

The process by which the Lo Contador farm becomes the North Pedro de Valdivia neighborhood, and thus a constituent part of the city of Santiago, speaks precisely of the complexity and the richness of these oscillating relationships between different scales that so strongly characterize the objects that architecture can offer to the city. ARa

\section{Bibliography}

Amenabar, Pilar; Guerrero, Francisco and Larach, Carmen Gloria. Lo Contador un nuevo destino. Architectural Degree Project. Catholic Univer sity of Chile, 1975. / Castedo, Leopoldo and Encina, Francisco. Resumen de la Historia de Chile, Editorial Zig-Zag, Santiago, 1954. / Evans, Robin. Translation from drawing to building and other essays. MIT Press, Cambridge, 1997. / Irarrázaval, Raúl. La casa patronal. Santiago, 1969. / Lama, Antonio Campus El Conquistador. In Revista ARQ 8, Nov 1983, pp. 10-12. / Larraín, Carlos J. Las Condes. Nascimiento, Santiago, 1952. / Meza, Fernán. Lo Contador. Degree Seminar, University of Chile, 1961. / Palmer, Montserrat. La comuna de Providencia y la ciudad jardín. Pontificia Universidad Católica de Chile, Facultad de Arquitectura y Bellas Artes, Santiago, 1984. / Rosales, Abel. Historia y tradiciones del puente de Cal y Canto. Manuel A. Mujica (ed). Imprenta Estrella de Chile, Santiago, 1888.

4 Lo Contador. Family Tree of Diego Martinez 1901. Prepared by José Pedro Alessand 15 Santiago: Army Map 1895-1905. Military Geographic Institute 